\title{
Kinetics and Mechanism of the Pyridinolysis of Methyl Phenyl Phosphinic Chloride in Acetonitrile
}

\author{
Keshab Kumar Adhikary and Hai Whang Lee* \\ Department of Chemistry, Inha University, Incheon 402-751, Korea. *E-mail: hwlee@inha.ac.kr \\ Received April 8, 2011, Accepted April 26, 2011
}

\begin{abstract}
The pyridinolysis of methyl phenyl phosphinic chloride is investigated kinetically in acetonitrile at $-20.0{ }^{\circ} \mathrm{C}$. The Hammett and Brönsted plots for substituent $\mathrm{X}$ variations in the nucleophiles are biphasic concave downwards with a break point at $\mathrm{X}=\mathrm{H}$, and unusual positive $\rho_{\mathrm{X}}(=2.94)$ and negative $\beta_{\mathrm{X}}(=-0.48)$ values are obtained for the strongly basic nucleophiles. A stepwise mechanism with a rate-limiting step change from bond breaking for the weakly basic pyridines to bond formation for the strongly basic pyridines is proposed on the basis of biphasic concave downward Hammett and Brönsted plots. Unusual positive $\rho_{\mathrm{X}}$ and negative $\beta_{\mathrm{X}}$ values are rationalized by the isokinetic relationship. The pyridinolyses and anilinolyses of four $\mathrm{R}_{1} \mathrm{R}_{2} \mathrm{P}(=\mathrm{O}) \mathrm{Cl}$-type substrates, dimethyl, diethyl, methyl phenyl, and diphenyl phosphinic chlorides in acetonitrile are compared to obtain systematic information on phosphoryl transfer reaction mechanism. The combination of the two ligands, $\mathrm{Me}$ and $\mathrm{Ph}$, shows unexpected kinetic results for both the anilinolysis and pyridinolysis: greatest magnitude of $k_{\mathrm{H}} / k_{\mathrm{D}}(=2.10)$ involving deuterated anilines $\left[\mathrm{XC}_{6} \mathrm{H}_{4} \mathrm{NH}_{2}\left(\mathrm{D}_{2}\right)\right]$ for the anilinolysis, and exceptionally fast rate and biphasic concave downward free energy correlation for the pyridinolysis.
\end{abstract}

Key Words : Phosphoryl transfer reaction, Pyridinolysis, Methyl phenyl phosphinic chloride, Biphasic concave downward free energy relationship, Isokinetic relationship

\section{Introduction}

In previous work, this lab studied the aminolyses of various types of phosphates and derivatives: pyridinolyses, ${ }^{1}$ anilinolyses, ${ }^{2}$ and theoretical studies. ${ }^{3}$ A dramatic substituent effects of the nucleophile (X) and/or substrate (Y) and/or leaving group $(\mathrm{Z})$ upon the reaction mechanism were observed for the pyridinolyses of select phosphates in acetonitrile $(\mathrm{MeCN})^{1 \mathrm{a}-\mathrm{i}, \mathrm{k}, \mathrm{l}}$ and DMSO: ${ }^{1 \mathrm{j}}$ (i) in bis(4-methoxyphenyl) Z-aryl phosphates [(4-MeOPhO $\left.)_{2} \mathrm{P}(=\mathrm{O}) \mathrm{OPhZ}\right]$, the Hammett and Brönsted plots for both substituent $\mathrm{X}$ and $Z$ variations were biphasic concave downwards; ${ }^{1 \mathrm{~b}}$ (ii) in $O, O$-diphenyl Z-S-aryl phosphorothioates $\left[(\mathrm{PhO})_{2} \mathrm{P}(=\mathrm{O}) \mathrm{SPhZ}\right]$, the Hammett plots for substituent $Z$ variations were biphasic concave downwards, and the $\rho_{Z}$ value was unusually negative for electron-withdrawing while positive for electron-donating substituent $\mathrm{Z} ;{ }^{1 \mathrm{e}}$ (iii) in $\mathrm{Z}$ - $N$-aryl- $P, P$-diphenyl phosphinic amides $\left[\mathrm{Ph}_{2} \mathrm{P}(=\mathrm{O}) \mathrm{NHPhZ}\right]$, the Hammett plots for substituent $\mathrm{Z}$ variations were biphasic concave upwards, and the $\rho_{Z}$ value was positive for electron-withdrawing while unusually negative for electron-donating substituent $\mathrm{Z} ;{ }^{1 \mathrm{j}}$ (iv) in Y-aryl phenyl isothiocyanophosphates [(YPhO)$(\mathrm{PhO}) \mathrm{P}(=\mathrm{O}) \mathrm{NCS}]$, the Hammett plots for substituent $\mathrm{Y}$ variations exhibited biphasic concave downwards, while those for substituent $\mathrm{X}$ variations exhibited biphasic concave upwards; ${ }^{1 \mathrm{c}}$ (v) in Y-aryl phenyl chlorothiophosphates $[(\mathrm{YPhO})(\mathrm{PhO}) \mathrm{P}(=\mathrm{S}) \mathrm{Cl}]$, the Hammett and Brönsted plots for substituent $\mathrm{X}$ variations were biphasic concave upwards, while the Hammett plots for substituent $\mathrm{Y}$ variations were biphasic concave downwards; ${ }^{1 \mathrm{k}}$ (vi) in $\mathrm{Y}-\mathrm{O}$-aryl methyl phosphonochloridothioates [(YPhO) $\mathrm{MeP}(=\mathrm{S}) \mathrm{Cl}]$, the Ham- mett and Brönsted plots for substituent $\mathrm{X}$ variations were discrete biphasic with a break region, while the Hammett plots for substituent $\mathrm{Y}$ variations were biphasic concave downwards; ${ }^{11}$ (vii) in dimethyl thiophsphate $\left[(\mathrm{MeO})_{2} \mathrm{P}(=\mathrm{S}) \mathrm{Cl}\right],{ }^{1 \mathrm{~g}}$ diethyl thiophsphate $\left[(\mathrm{EtO})_{2} \mathrm{P}(=\mathrm{S}) \mathrm{Cl}\right],^{1 \mathrm{~g}}$ dimethyl phosphinic chloride $\left[\mathrm{Me}_{2} \mathrm{P}(=\mathrm{O}) \mathrm{Cl}\right],{ }^{1 \mathrm{~h}}$ dimethyl thiophosphinic chloride $\left[\mathrm{Me}_{2} \mathrm{P}(=\mathrm{S}) \mathrm{Cl}\right],{ }^{\text {th }}$ and diphenyl thiophosphinic chloride $\left[\mathrm{Ph}_{2} \mathrm{P}(=\mathrm{S}) \mathrm{Cl}\right],{ }^{1 \mathrm{~d}}$ the free energy correlations for substituent $\mathrm{X}$ variations were biphasic concave upwards. It needs to be stressed that the unusual positive $\rho_{\mathrm{X}}$ value was obtained at $-25.0{ }^{\circ} \mathrm{C}$ for the weakly basic pyridines in dimethyl phosphinic chloride, and rationalized by the isokinetic relationship in which the negative $\rho_{\mathrm{X}}$ values were observed at -20.0 and $-15.0{ }^{\circ} \mathrm{C}$ with isokinetic temperature, $t_{\text {isokinetic }}=-23.8$ ${ }^{\circ} \mathrm{C} .{ }^{\text {h }}$ In contrast to (i)-(vii), the pyridinolyses of Y-aryl phenyl chlorophosphates $[(\mathrm{YPhO})(\mathrm{PhO}) \mathrm{P}(=\mathrm{O}) \mathrm{Cl}],{ }^{1 \mathrm{a}} \mathrm{Y}-\mathrm{O}-$ aryl phenyl phosphonochloridothioates $[(\mathrm{YPhO}) \mathrm{PhP}(=\mathrm{S}) \mathrm{Cl}],{ }^{1 \mathrm{f}}$ diphenyl phosphinic chloride $\left[\mathrm{Ph}_{2} \mathrm{P}(=\mathrm{O}) \mathrm{Cl}\right]{ }^{1 \mathrm{~d}}$ dimethyl phosphate $\left[(\mathrm{MeO})_{2} \mathrm{P}(=\mathrm{O}) \mathrm{Cl}\right]{ }^{1 \mathrm{~g}}$ diethyl phosphate $\left[(\mathrm{EtO})_{2}-\right.$ $\mathrm{P}(=\mathrm{O}) \mathrm{Cl}],{ }^{1 \mathrm{~g}}$ and diethyl phosphinic chloride $\left[\mathrm{Et}_{2} \mathrm{P}(=\mathrm{O}) \mathrm{Cl}\right]^{1 \mathrm{i}}$ in $\mathrm{MeCN}$ showed linear free energy correlations. However, the anilinolyses of phosphates and derivatives (twenty substrates) in $\mathrm{MeCN}^{2 \mathrm{a}-1}$ and $\mathrm{DMSO}^{2 \mathrm{~m}}$ showed linear free energy correlations, except $\mathrm{Y}-\mathrm{O}$-aryl methyl phosphonochloridothioates $[(\mathrm{YPhO}) \mathrm{MeP}(=\mathrm{S}) \mathrm{Cl}]$ where the Hammett and Brönsted plots for substituent $\mathrm{X}$ variations were biphasic concave downwards with a discrete break region. ${ }^{2 \mathrm{k}}$

In the present work, the reactions of methyl phenyl phosphinic chloride $[3 ; \mathrm{MePhP}(=\mathrm{O}) \mathrm{Cl}]$ with substituted $\mathrm{X}$ pyridines are investigated kinetically in $\mathrm{MeCN}$ at $-20.0 \pm$ $0.1{ }^{\circ} \mathrm{C}$ to gain further understanding of phosphoryl transfer 
reaction mechanism (eq. 1). The kinetic results of the pyridinolyses and anilinolyses of four $\mathrm{R}_{1} \mathrm{R}_{2} \mathrm{P}(=\mathrm{O})$ Cl-type substrates are discussed on the basis of steric effects of $R_{1}$ and $R_{2}$, inductive effects of ligands $\left(R_{1}\right.$ and $\left.R_{2}\right)$ on the reactivity of substrate, and mechanism of the pyridinolysis and anilinolysis. Employed substrates are dimethyl (1), ${ }^{1 \mathrm{~h}}$ diethyl (2), ${ }^{1 \mathrm{i}}$ methyl phenyl (3), and diphenyl phosphinic chloride (4), ${ }^{1 \mathrm{~d}}$ in which the alkyl and/or phenyl ligands are bonded directly to the phosphorus atom reaction center in the substrate. The numbering of the substrates (1-4) follows the sequence of the size of the two ligands $\left(R_{1}\right.$ and $\left.R_{2}\right)$.

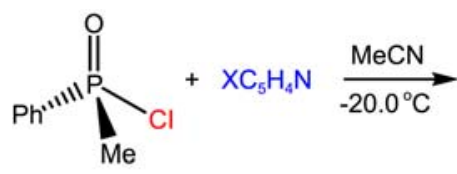

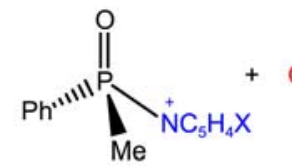

(3)

$\mathrm{X}=4-\mathrm{NH}_{2}, 4-\mathrm{MeO}, 4-\mathrm{Me}, \mathrm{H}, 3-\mathrm{Cl}, 4-\mathrm{Ac}, 3-\mathrm{CN}, 4-\mathrm{CN}$

\section{Results and Discussion}

The reactions were carried out under pseudo-first-order conditions with a large excess of pyridine. The observed pseudo-first-order rate constants $\left(k_{\text {obsd }}\right)$ for all reactions obeyed eq. (2) with negligible $k_{0}(=0)$ in $\mathrm{MeCN}$. The secondorder rate constants were determined with at least five pyridine concentrations. The linear plots of eq. (2) suggest a lack of any base-catalysis or side reactions, and the overall reaction is described by eq. (1).

$$
k_{\text {obsd }}=k_{0}+k_{2}\left[\mathrm{XC}_{5} \mathrm{H}_{4} \mathrm{~N}\right]
$$

The second-order rate constants $\left[k_{2}\left(\mathrm{M}^{-1} \mathrm{~s}^{-1}\right)\right]$ are summarized in Table 1. The substituent effects of the weakly basic nucleophiles, $\mathrm{X}=(\mathrm{H}, 3-\mathrm{Cl}, 4-\mathrm{Ac}, 3-\mathrm{CN}, 4-\mathrm{CN})$, upon the pyridinolysis rates correlate with those for a typical nucleophilic substitution reaction, giving negative $\rho_{\mathrm{x}}$ $(=-6.91 \pm 0.28)$ and positive $\beta_{\mathrm{X}}(=1.17 \pm 0.57)$ values. However, contrary to the typical nucleophilic substitution reaction, unusual positive $\rho_{\mathrm{x}}(=2.94 \pm 0.12)$ and negative $\beta_{\mathrm{X}}(=-0.48 \pm 0.18)$ values are obtained for the strongly basic nucleophiles, $\mathrm{X}=\left(4-\mathrm{NH}_{2}, 4-\mathrm{MeO}, 4-\mathrm{Me}, \mathrm{H}\right)$. As a result, both the Hammett $\left(\log k_{2} v s \sigma_{\mathrm{X}}\right)$ and Brönsted [log $k_{2}$ vs $\left.\mathrm{p} K_{\mathrm{a}}(\mathrm{X})\right]$ plots are biphasic concave downwards with a break point at $\mathrm{X}=\mathrm{H}$ as seen in Figure 1. Biphasic concave downward free energy correlation was not observed previously for the pyridinolysis of $\mathrm{R}_{1} \mathrm{R}_{2} \mathrm{P}(=\mathrm{O}$ or $\mathrm{S})$ Cl-type substrates. The Brönsted $\beta_{\mathrm{X}}$ value was calculated by correlating $\log k_{2}(\mathrm{MeCN})$ with $\mathrm{p} K_{\mathrm{a}}\left(\mathrm{H}_{2} \mathrm{O}\right){ }^{4}$, which was justified theoretically and experimentally. ${ }^{5}$
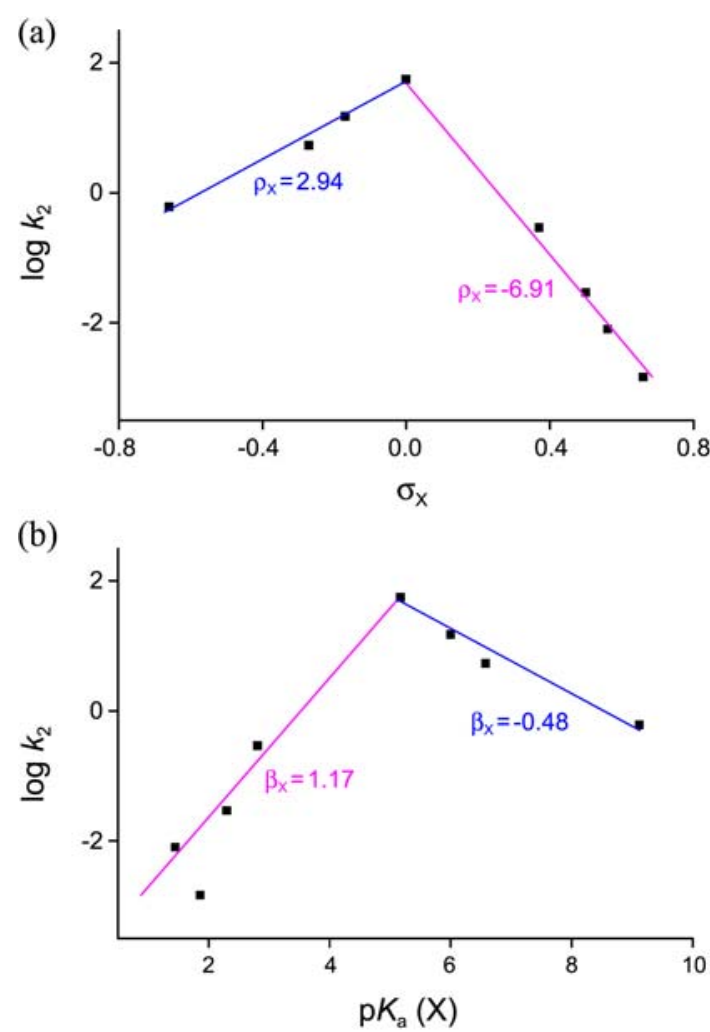

Figure 1. The Hammett (a) and Brönsted (b) plots of the reactions of $3[\mathrm{MePhP}(=\mathrm{O}) \mathrm{Cl}]$ with X-pyridines in $\mathrm{MeCN}$ at $-20.0^{\circ} \mathrm{C}$.

Table 2 shows the summations of inductive effects of the two ligands $\left[\sum \sigma_{\mathrm{I}}=\sigma_{\mathrm{I}}\left(\mathrm{R}_{1}\right)+\sigma_{\mathrm{I}}\left(\mathrm{R}_{2}\right)\right]{ }^{6}$, natural bond order (NBO) charges at the reaction center $\mathrm{P}$ atom in the gas phase [B3LYP/6-311+G(d,p) level of theory], ${ }^{2 \mathrm{e}}$ summations of Taft's steric constants of the two ligands $\left[\Sigma E_{\mathrm{S}}=E_{\mathrm{S}}\left(\mathrm{R}_{1}\right)+\right.$ $\left.E_{\mathrm{S}}\left(\mathrm{R}_{2}\right)\right]{ }^{7}$ second-order rate constants $k_{\mathrm{Py}}$ (pyridinolysis) at 35.0 and $k_{\mathrm{An}}$ (anilinolysis) at $55.0{ }^{\circ} \mathrm{C}$, and Brönsted coefficients $\left(\beta_{\mathrm{X}, \mathrm{Py}}\right.$ and $\left.\beta_{\mathrm{X}, \mathrm{An}}\right)$ for the pyridinolyses and anilinolyses of four $\mathrm{R}_{1} \mathrm{R}_{2} \mathrm{P}(=\mathrm{O})$ Cl-type in $\mathrm{MeCN}$. The plots of $\Sigma \sigma_{\mathrm{I}}$ against the NBO charge on $\mathrm{P}$ yield the slopes of $5.24(\mathrm{r}=$ $0.879)$ with four substrates, while the slopes of $5.08(\mathrm{r}=$ 0.998 ) with three substrates, $\mathbf{1}, \mathbf{3}$, and $\mathbf{4}$. The NBO charge at $\mathrm{P}$ atom can be treated as the parameter of the electrophilicity of the substrate. The magnitudes of the $\beta_{\mathrm{X}}$ values of the anilinolyses are greater than those of the pyridinolyses.

The pyridinolysis rate is rather faster than the anilinolysis rate, ${ }^{8}$ even taking into account the greater basicity of pyridine than aniline, $\mathrm{p} K_{\mathrm{a}}($ aniline $)=10.56$ and $\mathrm{p} K_{\mathrm{a}}($ pyridine $)=$ 12.33 in $\mathrm{MeCN} ;{ }^{9} \mathrm{p} K_{\mathrm{a}}($ aniline $)=4.60^{10}$ and $\mathrm{p} K_{\mathrm{a}}($ pyridine $)=$ 5.17 in water at $25.0{ }^{\circ} \mathrm{C}$. Solely considering the electrophilicity (or NBO charge on $\mathrm{P}$ ) of the $\mathrm{P}$ reaction center, the pyridinolysis and anilinolysis rate should be the sequence of $\mathbf{4}>\mathbf{3}>\mathbf{2}>\mathbf{1}$. However, the sequence of the anilinolysis rate,

Table 1. Second-Order Rate Constants $\left(k_{2} \times 10^{1} / \mathrm{M}^{-1} \mathrm{~s}^{-1}\right)$ of the Reactions of $3[\mathrm{MePhP}(=\mathrm{O}) \mathrm{Cl}]$ with $\mathrm{XC}_{5} \mathrm{H}_{4} \mathrm{~N}$ in $\mathrm{MeCN}$ at $-20.0^{\circ} \mathrm{C}$

\begin{tabular}{ccccccccc}
\hline $\mathrm{X}$ & $4-\mathrm{NH}_{2}$ & $4-\mathrm{MeO}$ & $4-\mathrm{Me}$ & $\mathrm{H}$ & $3-\mathrm{Cl}$ & $4-\mathrm{Ac}$ & $3-\mathrm{CN}$ & $4-\mathrm{CN}$ \\
\hline$k_{2} \times 10^{1}$ & $6.10 \pm 0.05$ & $54.1 \pm 0.2$ & $151 \pm 1$ & $558 \pm 10$ & $2.90 \pm 0.16$ & $0.293 \pm 0.002$ & $0.0795 \pm 0.0010$ & $0.0147 \pm 0.0001$ \\
\hline
\end{tabular}


Table 2. Summary of Summations of Inductive Effects of the Two Ligands $\left(\Sigma \sigma_{\mathrm{I}}\right)$, NBO Charges at Reaction Center P, Summations of Steric Constants of the Two Ligands $\left(\Sigma E_{\mathrm{S}}\right)$, Second-Order Rate Constants $\left(k_{\mathrm{Py}}\right.$ at $35.0{ }^{\circ} \mathrm{C}$ and $k_{\mathrm{An}}$ at $\left.55.0{ }^{\circ} \mathrm{C}\right)$, and Brönsted Coefficients $\left(\beta_{\mathrm{X}, \mathrm{Py}}\right.$ and $\left.\beta_{\mathrm{X}, \mathrm{An}}\right)$ for the Pyridinolyses and Anilinolyses of Four $\mathrm{R}_{1} \mathrm{R}_{2} \mathrm{P}(=\mathrm{O})$ Cl-type in MeCN

\begin{tabular}{cccccccccc}
\hline Sub & $\mathrm{R}_{1}$ & $\mathrm{R}_{2}$ & $\Sigma \sigma_{\mathrm{I}}$ & charge at P & $\Sigma E_{\mathrm{S}}$ & $10^{3}{k_{\mathrm{Py}}}{ }^{a}$ & $10^{3} k_{\mathrm{An}}{ }^{d}$ & $\beta_{\mathrm{X}, \mathrm{Py}}$ & $\beta_{\mathrm{X}, \mathrm{An}}$ \\
\hline $\mathbf{1}$ & $\mathrm{Me}$ & $\mathrm{Me}$ & -0.02 & 1.793 & 0.00 & $102,000^{b}$ & $7,820^{e}$ & $0.17^{g} /-0.03^{h}$ & $1.62^{m}$ \\
$\mathbf{2}$ & $\mathrm{Et}$ & $\mathrm{Et}$ & -0.02 & 1.817 & -0.14 & 127 & $189^{f}$ & $0.45^{i}$ & $0.56^{n}$ \\
$\mathbf{3}$ & $\mathrm{Me}$ & $\mathrm{Ph}$ & 0.11 & 1.821 & -2.48 & $126,000^{c}$ & 138 & $-0.48^{j} / 1.17^{k}$ & $1.35^{\circ}$ \\
$\mathbf{4}$ & $\mathrm{Ph}$ & $\mathrm{Ph}$ & 0.24 & 1.844 & -4.96 & 54.6 & 1.73 & $0.68^{l}$ & $1.69^{\circ}$ \\
\hline
\end{tabular}

${ }^{a}$ Second-order rate constant with unsubstituted pyridine $(\mathrm{X}=\mathrm{H})$ at $35.0^{\circ} \mathrm{C} .{ }^{b}$ Extrapolated value in the Arrhenius plot with kinetic data: $k_{2}=34,300$, 40,400 , and $53,900 \times 10^{-3} \mathrm{M}^{-1} \mathrm{~s}^{-1}$ at $-25.0,-15.0$, and $-5.0{ }^{\circ} \mathrm{C}$, respectively. ${ }^{c}$ Extrapolated value in the Arrhenius plot with kinetic data: $k_{2}=46,100$, 50,300 , and $55,800 \times 10^{-3} \mathrm{M}^{-1} \mathrm{~s}^{-1}$ at $-30.0,-25.0$, and $-20.0^{\circ} \mathrm{C}$, respectively. ${ }^{d}$ Second-order rate constant with unsubstituted aniline $(\mathrm{X}=\mathrm{H})$ at $55.0{ }^{\circ} \mathrm{C}$. ${ }^{e}$ Extrapolated value in the Arrhenius plot with kinetic data: $k_{2}=776,1,010$, and $1,610 \times 10^{-3} \mathrm{M}^{-1} \mathrm{~s}^{-1}$ at $0.0,5.0$, and $15.0^{\circ} \mathrm{C}$, respectively. ${ }^{f}$ Extrapolated value in the Arrhenius plot with kinetic data: $k_{2}=117,162$, and $211 \times 10^{-3} \mathrm{M}^{-1} \mathrm{~s}^{-1}$ at $40.0,50.0$, and $60.0^{\circ} \mathrm{C}$, respectively. ${ }^{g} \mathrm{The}$ value at $-25.0^{\circ} \mathrm{C}$. For $\mathrm{X}$ $=(4-\mathrm{MeO}, 4-\mathrm{Me}, 3-\mathrm{Me}, \mathrm{H}, 3-\mathrm{Ph}) .{ }^{h}$ The value at $-25.0^{\circ} \mathrm{C}$. For $\mathrm{X}=(3-\mathrm{MeO}, 3-\mathrm{Cl}, 3-\mathrm{Ac}, 4-\mathrm{Ac}, 3-\mathrm{CN}, 4-\mathrm{CN}) .{ }^{i} \mathrm{The}$ value at $45.0{ }^{\circ} \mathrm{C} .{ }^{j} \mathrm{The}$ value at -20.0 ${ }^{\circ} \mathrm{C}$. For $\mathrm{X}=\left(4-\mathrm{NH}_{2}, 4-\mathrm{MeO}, 4-\mathrm{Me}, \mathrm{H}\right) .{ }^{k}$ The value at $-20.0{ }^{\circ} \mathrm{C}$. For $\mathrm{X}=(\mathrm{H}, 3-\mathrm{Cl}, 4-\mathrm{Ac}, 3-\mathrm{CN}, 4-\mathrm{CN}) .{ }^{l} \mathrm{The}$ value at $35.0{ }^{\circ} \mathrm{C} .{ }^{m} \mathrm{The}$ value at $15.0{ }^{\circ} \mathrm{C} .{ }^{n} \mathrm{The}$ value at $50.0{ }^{\circ} \mathrm{C} .{ }^{\circ}$ The value at $55.0{ }^{\circ} \mathrm{C}$.

$\mathbf{1}>\mathbf{2}>\mathbf{3}>>\mathbf{4}$, is completely opposite to expectations for the inductive effects of the two ligands and the sequence of the pyridinolysis rate, $\mathbf{3}>\mathbf{1}>\mathbf{2}>\mathbf{4}$, is somewhat wandering.

The approach of the $\mathrm{X}$-aniline nucleophile to the $\mathrm{P}$ reaction center should cause extensive steric hindrance when the attacking and leaving groups occupy apical positions in a trigonal bipyramidal pentacoordinate transition state (TBP5C TS) of a backside attack (Scheme 1), because of not only a relatively large size of the $\mathrm{X}$-aniline nucleophile, but also the orientation restriction of the attacking $\mathrm{X}$-aniline. The lone pair of the amino nitrogen is $\mathrm{sp}^{3}$-type, thus the angle of $\mathrm{C}(\alpha$-carbon of phenyl ring $)-\mathrm{N}$ (amino nitrogen $)-\mathrm{P}($ reaction center of substrate) would be $>109.5^{\circ}$ in the TS. The degree of steric hindrance would thus be greater as the ligands of $\mathrm{R}_{1}$ and $\mathrm{R}_{2}$ become bulkier in the TS. In contrast, the pyridine ring, located more or less parallel to the attacking axis in the TBP-5C TS, would experience much less steric congestion compared to the phenyl ring of the aniline. These statements rationalize that the predominant factor to determine the anilinolysis rates of $\mathrm{R}_{1} \mathrm{R}_{2} \mathrm{P}(=\mathrm{O}) \mathrm{Cl}$ in $\mathrm{MeCN}$ is the degree of steric hindrance of the two ligands over the electrophilicity of the $\mathrm{P}$ reaction center, while the steric effects of the two ligands are not major factor to determine the pyridinolysis rate. The degree of steric hindrance would thus be greater as the ligands of $\mathrm{R}_{1}$ and $\mathrm{R}_{2}$ become bulkier for anilinolysis. Consequently, frontside attack with a hydrogen bonded, four-center-type TS could be an alternative pathway competing with the backside nucleophilic attack when the steric hindrance is great, especially for $\mathrm{P}=\mathrm{S}$ system with a relatively

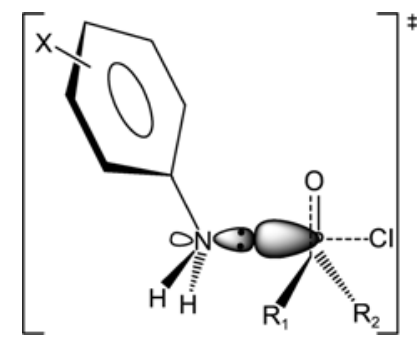

Scheme 1. TS of a backside attack of $\mathrm{X}$-aniline towards the $\mathrm{Cl}$ leaving group. small electrophilicity. ${ }^{2}$

The second-order rate constants for the anilinolyses of four phosphinic chlorides gave the relative rates of 4,520 $(\mathbf{1})^{2 \mathrm{i}}: 109(\mathbf{2})^{2 \mathrm{l}}: 80(\mathbf{3})^{2 \mathrm{i}}: 1(\mathbf{4})^{2 \mathrm{~d}}$ in $\mathrm{MeCN}$ at $55.0^{\circ} \mathrm{C}$. A plot of $\log k_{2}$ (with $\mathrm{C}_{6} \mathrm{H}_{5} \mathrm{NH}_{2}$ ) of four phosphinic chlorides against the Taft's steric constants according to eq, $\log k_{2}=\delta \Sigma E_{\mathrm{S}}+\mathrm{C}$, gave the great sensitivity coefficient of the steric effects, $\delta=$ $0.572(\mathrm{r}=0.895)$, while $\delta=0.737(\mathrm{r}=0.999)$ for three phosphinic chlorides $(\mathbf{1}, \mathbf{3}$, and $\mathbf{4})$. There is no doubt that the sequence of the anilinolysis rates of the phosphinic chlorides is inversely proportional to the size of the two ligands; $\mathrm{Ph}, \mathrm{Ph}$ (4) $>$ Ph,Me (3) $>$ Et,Et (2) $>$ Me,Me (1).

The sequence of the second-order rate constants of the pyridinolyses does not show systematic consistency with $\Sigma \sigma_{\text {I }}$, NBO charge at $\mathrm{P}$, or $\Sigma E_{\mathrm{S}}$, indicating that the pyridinolysis rates of $\mathrm{R}_{1} \mathrm{R}_{2} \mathrm{P}(=\mathrm{L}) \mathrm{Cl}$ in $\mathrm{MeCN}$ are not dependent upon one dominant factor but on many factors. Meanwhile, the pyridinolysis rate of $\mathbf{3}$ is exceptionally fast, even slightly faster than that of $\mathbf{1}$. The anilinolysis of $\mathbf{3}$ also showed an unexpected result regarding the mechanism. Although the anilinolysis rates of four phosphinic chlorides are quantitatively substantiated by the degree of steric hindrance as discussed earlier, the sequence of the magnitudes of deuterium kinetic isotope effects (DKIEs; $k_{\mathrm{H}} / k_{\mathrm{D}}$ ) involving deuterated X-aniline $\left(\mathrm{XC}_{6} \mathrm{H}_{4} \mathrm{ND}_{2}\right), k_{\mathrm{H}} / k_{\mathrm{D}}=1.62-2.10(3)^{2 \mathrm{i}, 11}$ $>1.42-1.82(\mathbf{4})^{2 \mathrm{~d}}>0.828-0.974(\mathbf{2})^{2 \mathrm{l}}>0.703-0.899(\mathbf{1}),{ }^{2 \mathrm{i}}$ is inconsistent with the degree of steric hindrance of the two ligands or with any other factor. These results imply that a subtle combination of large $(\mathrm{Ph})$ and small $(\mathrm{Me})$ ligands in $\mathbf{3}$ leads to an unexpected result, i.e., a greater fraction of a frontside nucleophilic attack involving a hydrogen bonded, four-center-type TS compared to two large phenyl ligands in

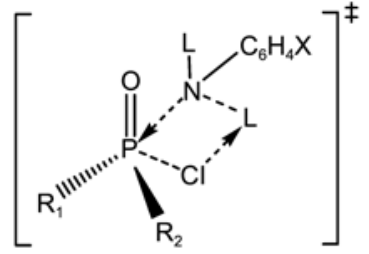

Frontside attack TS ( $\mathrm{L}=\mathrm{H}$ or $\mathrm{D})$
Backside attack TS

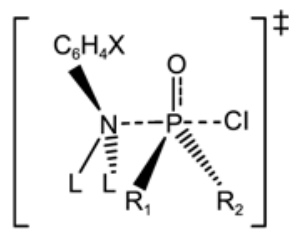


4. In other words, a frontside attack with a hydrogen bonded, four-center-type TS is energetically more favorable than a backside nucleophilic attack TS for the anilinolysis of $\mathbf{3}^{11}$

In the pyridinolyses of $O, O$-diphenyl $\mathrm{Z}-\mathrm{S}$-phenyl phosphorothioates, ${ }^{1 \mathrm{e}}$ a stepwise mechanism with a rate-limiting leaving group expulsion from the intermediate was proposed based on the positive cross-interaction constant (CIC), ${ }^{12} \rho_{\mathrm{XZ}}$ $(=0.76)$, value when $\sigma_{\mathrm{Z}} \geq 0$, and a concerted mechanism was proposed based on the negative $\rho_{\mathrm{XZ}}(=-1.54)$ when $\sigma_{Z} \leq 0$. The anomalous negative sign of $\rho_{Z}$ with electronwithdrawing $Z$ substituents was interpreted as the intramolecular ligand exchange process of the leaving group from the equatorial position in the intermediate to the apical position in the TS. The $\pi$-cloud of the phenyl ring in the "electronpoor" leaving group with electron-withdrawing Z substituent interacts strongly with the $\pi$-cloud of the phenyl ring in the adjacent "electron-rich" phenoxy group by through-space interaction in a TBP-5C intermediate, resulting in negative sign of $\rho$. $^{1 \mathrm{e}}$

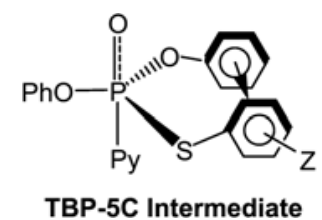

In the pyridinolyses of $\mathrm{Z}$ - $N$-aryl- $P, P$-diphenyl phosphinic amides, ${ }^{1 \mathrm{j}}$ a concerted mechanism was proposed based on the negative $\rho_{\mathrm{XZ}}(=-1.54$ and -0.27 for electron-donating and -withdrawing substituent $Z$, respectively) values. ${ }^{12}$ To rationalize the unusual negative $\rho_{\mathrm{Z}}$ value for electrondonating substituents $Z$, the TBP-5C TS involving a frontside nucleophilic attack was proposed. When both the leaving group and nucleophile occupy the equatorial positions in a TBP-5C TS, the $\pi$-cloud of the phenyl ring in the "electron-rich" leaving group interacts strongly with the $\pi$-cloud of the pyridine ring in the adjacent equatorial position by through-space interaction.

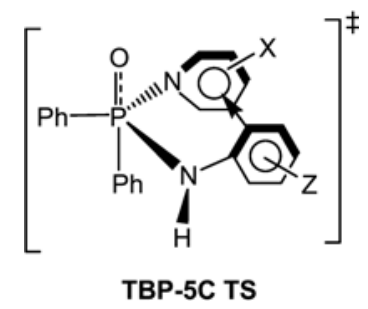

In the pyridinolyses of $\mathbf{1}$ at $-25.0^{\circ} \mathrm{C},{ }^{1 \mathrm{~h}}$ a concerted mechanism was proposed, and biphasic concave upward free energy relationship was interpreted as a change of nucleophilic attacking direction from a backside attack (TSb) for the weakly basic pyridines to a frontside attack (TSf) for the strongly basic pyridines. The unusual positive $\rho_{\mathrm{X}}$ and negative $\beta_{\mathrm{X}}$ values for the weakly basic pyridines were substantiated by isokinetic relationship, in which the positive $\rho_{\mathrm{X}}$ and negative $\beta_{\mathrm{X}}$ values could be observed at considerably low reaction temperature of $-25.0{ }^{\circ} \mathrm{C}$. Empirical kinetic results showed that the $\rho_{\mathrm{X}}$ value changes from +0.16 (positive) via -0.34 (negative) to -0.38 (negative) as the reaction temperature is raised from -25.0 via -20.0 to $-15.0^{\circ} \mathrm{C}$, resulting in $t_{\text {isokinetic }}=-23.8^{\circ} \mathrm{C} . .^{\mathrm{h}}$
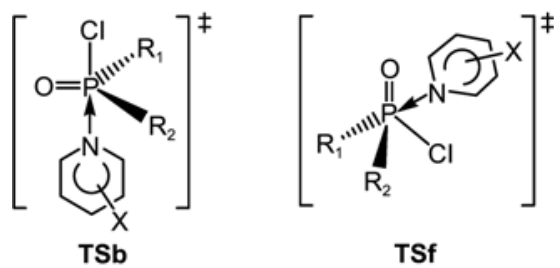

The concerted $\mathrm{S}_{\mathrm{N}} 2$ mechanism was proposed for the anilinolyses of 1-4, and the attacking direction of the aniline nucleophile towards the $\mathrm{Cl}$ leaving group was suggested on the basis of DKIEs: predominant backside attack for $\mathbf{1}\left(k_{\mathrm{H}} / k_{\mathrm{D}}\right.$ $=0.703-0.899)$; backside attack and partial frontside attack for $2\left(k_{\mathrm{H}} / k_{\mathrm{D}}=0.828-0.97\right)$; almost frontside attack for $\mathbf{3}$ $\left(k_{\mathrm{H}} / k_{\mathrm{D}}=1.62-2.10\right)$; predominant frontside attack for 4 $\left(k_{\mathrm{H}} / k_{\mathrm{D}}=1.42-1.82\right)$. The concerted mechanism was proposed for the pyridinolyses of $\mathbf{1 , 2}$, and $\mathbf{4}$, and, as mentioned earlier, concave upward free energy relationship for substituent $\mathrm{X}$ variations was obtained for 1 . The concave upward Hammett and Brönsted plots for substituent $\mathrm{X}$ variations were also observed for the pyridinolyses of all the studied $\mathrm{R}_{1} \mathrm{R}_{2} \mathrm{P}(=\mathrm{S})$ Cl-type substrates: dimethyl thiophosphinic chloride $\left[\mathrm{Me}_{2} \mathrm{P}(=\mathrm{S}) \mathrm{Cl}\right]^{1 \mathrm{~h}}$, dimethyl $\left[(\mathrm{MeO})_{2} \mathrm{P}(=\mathrm{S}) \mathrm{Cl}\right]^{1 \mathrm{~g}}$ and diethyl $\left[(\mathrm{EtO})_{2} \mathrm{P}(=\mathrm{S}) \mathrm{Cl}\right]^{1 \mathrm{~g}}$ chlorothiophosphates, and diphenyl thiophosphinic chloride $\left[\mathrm{Ph}_{2} \mathrm{P}(=\mathrm{S}) \mathrm{Cl}\right]{ }^{1 \mathrm{~d}}$ The biphasic concave upward Hammett and Brönsted plots for substituent $\mathrm{X}$ variations were substantiated by a change in the attacking direction of the nucleophile from a frontside attack for the strongly basic pyridines to a backside attack for the weakly basic pyridines.

In general, the nonlinear free energy correlation of a concave upward plot is diagnostic of a change in the reaction mechanism, such as parallel reactions where the reaction path is changed depending on the substituents, while nonlinear free energy correlation of the biphasic concave downward plot is diagnostic of a rate-limiting step change from bond breaking with less basic nucleophiles to bond formation with more basic nucleophiles. ${ }^{13}$

In the present work, the authors propose a stepwise mechanism with a rate-limiting step change from bond breaking for the weakly basic pyridines to bond formation for the strongly basic pyridines on the basis of: (i) biphasic concave downward Hammett and Brönsted plots for substituent $\mathrm{X}$ variations with a break point at $\mathrm{X}=\mathrm{H}$, and (ii) smaller magnitude of $\beta_{\mathrm{X}}(=-0.48)$ value for the strongly basic pyridines and greater value of $\beta_{\mathrm{X}}(=1.17)$ for the weakly basic pyridines. The proposed stepwise mechanism of the present work is different from a concerted mechanism proposed for the pyridinolyses of $\mathbf{1}, \mathbf{2}$, and 4 . Taking into account the unexpected predominant frontside attack for the anilinolysis of $\mathbf{3}$, the attacking direction of the pyridine nucleophile seems to be a dominant frontside attack. Exceptional fast rate of the present work is hard to understand. All the unexpected kinetic results of the present work, biphasic 
concave downward free energy correlation, a stepwise mechanism, a predominant frontside attack, and exceptional fast rate may be attributed to a subtle combination of large ligand of phenyl and small ligand of methyl.

The additional anomaly of unusual positive value of $\rho_{\mathrm{X}}$ $(=2.94)$ and negative $\beta_{\mathrm{X}}(=-0.48)$ values for the strongly basic pyridines cannot be explained by desolvation of ground state ${ }^{14}$ or TS imbalance. ${ }^{15}$ Furthermore, throughspace interaction between pyridine and phenyl ring, as observed in the pyridinolysis of $\mathrm{Z}-N$-aryl- $P, P$-diphenyl phosphinic amides, ${ }^{1 \mathrm{j}}$ cannot be expected since the phenyl ligand and nucleophile are directly bonded to the $\mathrm{P}$ atom reaction center in the TS. As a result, the distance between the two rings is too far to interact even though two rings occupy equatorial positions in TBP-5C TS. Unusual phenomena are ascribed to the considerably low reaction temperature $\left(-20.0^{\circ} \mathrm{C}\right)$, as observed in the pyridinolyses of $\mathbf{1}$ for the weakly basic pyridines at $-25.0{ }^{\circ} \mathrm{C} .{ }^{\text {lh }}$ The isokinetic relationship is observed for a number of reaction series, and found that $\delta \Delta H^{\neq}$and $\delta \Delta S^{\neq}$are proportional. ${ }^{16}$ The values of $\Delta H^{\ddagger}=1.8$ and $8.4 \mathrm{kcal} \mathrm{mol}^{-1}$, and $\Delta S^{\neq}=-43.0$ and $-26.0 \mathrm{cal}$ $\mathrm{mol}^{-1} \mathrm{~K}^{-1}$ for $\mathrm{X}=\mathrm{H}$ and $4-\mathrm{NH}_{2}$, respectively, are obtained from the empirical kinetic data of $k_{2}\left(\mathrm{M}^{-1} \mathrm{~s}^{-1}\right)=46.1(-30.0)$, $50.3(-25.0)$, and $55.8\left(-20.0{ }^{\circ} \mathrm{C}\right)$ for $\mathrm{X}=\mathrm{H}$, and $k_{2}\left(\mathrm{M}^{-1} \mathrm{~s}^{-1}\right)$ $=3.71(-25.0), 6.10(-20.0)$, and $10.7\left(-10.0^{\circ} \mathrm{C}\right)$ for $\mathrm{X}=4-$ $\mathrm{NH}_{2}$. According to eq $\delta \Delta G^{\neq}=\delta \Delta H^{\neq}-T_{\text {isokinetic }} \delta \Delta S^{\neq}=0$, the isokinetic temperature, $T_{\text {isokinetic }}=287.5 \mathrm{~K}\left(t_{\text {isokinetic }}=+14.4\right.$ ${ }^{\circ} \mathrm{C}$ ), is obtained. ${ }^{17}$

In summary, the kinetic studies on the pyridinolysis of methyl phenyl phosphinic chloride have been carried out in $\mathrm{MeCN}$ at $-20.0^{\circ} \mathrm{C}$. The free energy correlations are biphasic concave downwards with a break point at $\mathrm{X}=\mathrm{H}$, and unusual positive $\rho_{\mathrm{X}}$ and negative $\beta_{\mathrm{X}}$ values are obtained for the strongly basic nucleophiles due to the isokinetic relationship. A stepwise mechanism with a rate-limiting step change from bond breaking for the weakly basic pyridines to bond formation for the strongly basic pyridines is proposed. The subtle combination of two ligands, $\mathrm{Me}$ and $\mathrm{Ph}$, shows unexpected kinetic results, such as, exceptionally fast rate and biphasic concave downward free energy correlation.

\section{Experimental Section}

Materals. GR grade methyl phenyl phosphinic chloride (2O) (min 97\%) was used without further purification. GR grade pyridines were used without further purification. HPLC grade acetonitrile (less than $0.005 \%$ water content) was used without further purification.

Kinetic Procedure. Conductometric rate measurements were carried out using self-made computer-aided automatic A/D converter conductivity bridges. The pseudo-first-order rate constants $\left(k_{\text {obsd }}\right)$ were determined as previously describ$\mathrm{ed}^{1 \mathrm{a}-\mathrm{i}}$ using large excess of nucleophiles, $[20]=0.002 \mathrm{M}$ and $\left[\mathrm{XC}_{5} \mathrm{H}_{4} \mathrm{~N}\right]=0.03-0.05 \mathrm{M}$. Each pseudo-first-order rate constants value $\left(k_{\text {obsd }}\right)$ was averaged obtained from more than three runs.

Product Analysis. Methyl phenyl phosphinic chloride was reacted with excess pyridine for more than 15 half-lives at $-20.0{ }^{\circ} \mathrm{C}$ in acetonitrile. The solvent was removed under reduced pressure. Analytical data of the products gave the following results:

$\left.\left(\mathrm{CH}_{3}\right)\left(\mathrm{C}_{6} \mathbf{H}_{5}\right) \mathbf{P}(=\mathbf{O})\left(\mathbf{N C}_{5} \mathrm{H}_{\mathbf{4}}-\mathbf{( 4 - C}(=\mathbf{O}) \mathbf{C H}_{3}\right)\right)$ : Light Brown crystalline solid, mp 135.0-136.0 ${ }^{\circ} \mathrm{C},{ }^{1} \mathrm{H}$ NMR $(200 \mathrm{MHz}$, $\left.\mathrm{CDCl}_{3}\right) \delta 1.65\left(3 \mathrm{H}, \mathrm{CH}_{3}, \mathrm{~d}, J=14.8 \mathrm{~Hz}\right), 2.77\left(3 \mathrm{H}, \mathrm{CH}_{3}, \mathrm{~s}\right)$, 7.39-7.78 (5H, aromatic, m), 8.33 (2H, Pyr, d, $J=6.4), 9.08$ (2H, Pyr, d, $J=6.4) ;{ }^{13} \mathrm{C}$ NMR (100 MHz, $\left.\mathrm{CDCl}_{3}\right) \delta 16.81$ $\left(1 \mathrm{C}, \mathrm{CH}_{3}, \mathrm{~d}, J=100 \mathrm{~Hz}\right), 26.99\left(1 \mathrm{C}, \mathrm{CH}_{3}, \mathrm{~s}\right), 128.42-132.09$ (6C, aromatic, m), 124.91 (2C, Pyr, s), 143.32 (1C, Pry, s), 148.79 (2C, Pyr., s), 193.71 (1C, C=O, s); ${ }^{31} \mathrm{P}$ NMR (162 $\left.\mathrm{MHz} \mathrm{CDCl}_{3}\right) \delta 49.82(1 \mathrm{P}, \mathrm{s}, \mathrm{P}=\mathrm{O})$; GC-MS $m / z, 295(\mathrm{M}+)$.

Acknowledgments. This work was supported by the Brain Korea 21 Program from National Research Foundation of Korea.

\section{References and Notes}

1. (a) Guha, A. K.; Lee, H. W.; Lee, I. J. Org. Chem. 2000, 65, 12. (b) Lee, H. W.; Guha, A. K.; Kim, C. K.; Lee, I. J. Org. Chem. 2002, 67, 2215. (c) Adhikary, K. K.; Lee, H. W.; Lee, I. Bull. Korean Chem. Soc. 2003, 24, 1135. (d) Hoque, M. E. U.; Dey, N. K.; Guha, A. K.; Kim, C. K.; Lee, B. S.; Lee, H. W. Bull. Korean Chem. Soc. 2007, 28, 1797. (e) Adhikary, K. K.; Lumbiny, B. J.; Kim, C. K.; Lee, H. W. Bull. Korean Chem. Soc. 2008, 29, 851. (f) Lumbiny, B. J.; Adhikary, K. K.; Lee, B. S.; Lee, H. W. Bull. Korean Chem. Soc. 2008, 29, 1769. (g) Dey, N. K.; Hoque, M. E. U.; Kim, C. K.; Lee, H. W. J. Phys. Org. Chem. 2010, 23, 1022. (h) Dey, N. K.; Adhikary, K. K.; Kim, C. K.; Lee, H. W. Bull. Korean Chem. Soc. 2010, 31, 3856. (i) Dey, N. K.; Kim, C. K.; Lee, H. W. Bull. Korean Chem. Soc. 2011, 32, 709. (j) Guha, A. K.; Kim, C. K.; Lee, H. W. J. Phys. Org. Chem. 2011, 24, 474. (k) Hoque, M. E. U.; Dey, S.; Kim, C. K.; Lee, H. W. Bull. Korean Chem. Soc. 2011, 32, 1138. (1) Guha, A. K.; Hoque, M. E. U.; Lee, H. W. Bull. Korean Chem. Soc. 2011, 32, 1375.

2. (a) Guha, A. K.; Lee, H. W.; Lee, I. J. Chem. Soc., Perkin Trans. 2 1999, 765. (b) Lee, H. W.; Guha, A. K.; Lee, I. Int. J. Chem. Kinet. 2002, 34, 632. (c) Hoque, M. E. U.; Dey, S.; Guha, A. K.; Kim, C. K.; Lee, B. S.; Lee, H. W. J. Org. Chem. 2007, 72, 5493. (d) Hoque, M. E. U.; Lee, H. W. Bull. Korean Chem. Soc. 2007, 28, 936. (e) Dey, N. K.; Han, I. S.; Lee, H. W. Bull. Korean Chem. Soc. 2007, 28, 2003. (f) Hoque, M. E. U.; Dey, N. K.; Kim, C. K.; Lee, B. S.; Lee, H. W. Org. Biomol. Chem. 2007, 5, 3944. (g) Dey, N. K.; Hoque, M. E. U.; Kim, C. K.; Lee, B. S.; Lee, H. W. J. Phys. Org. Chem. 2008, 21, 544. (h) Lumbiny, B. J.; Lee, H. W. Bull. Korean Chem. Soc. 2008, 29, 2065. (i) Dey, N. K.; Hoque, M. E. U.; Kim, C. K.; Lee, B. S.; Lee, H. W. J. Phys. Org. Chem. 2009, 22, 425. (j) Dey, N. K.; Kim, C. K.; Lee, H. W. Bull. Korean Chem. Soc. 2009, 30, 975. (k) Hoque, M. E. U.; Guha, A. K.; Kim, C. K.; Lee, B. S.; Lee, H. W. Org. Biomol. Chem. 2009, 7, 2919. (1) Dey, N. K.; Lee, H. W. Bull. Korean Chem. Soc. 2010, 31, 1403. (m) Dey, N. K.; Kim, C. K.; Lee, H. W. Org. Biomol. Chem. 2011, 9, 717

3. (a) Lee, I.; Kim, C. K.; Li, H. G.; Sohn, C. K.; Kim, C. K.; Lee, H. W.; Lee, B. S. J. Am. Chem. Soc. 2000, 122, 11162. (b) Han, I. S.; Kim, C. K.; Lee, H. W. Bull. Korean Chem. Soc. 2011, 32, 889.

4. (a) Fischer, A.; Galloway, W. J.; Vaughan, J. J. Chem. Soc. 1964, 3591. (b) Dean, J. A. Handbook of Organic Chemistry; McGrawHill: New York, 1987; Chapter 8.

5. (a) Lee, I.; Kim, C. K.; Han, I. S.; Lee, H. W.; Kim, W. K.; Kim, Y. B. J. Phys. Chem. B 1999, 103, 7302. (b) Coetzee, J. F. Prog. Phys. Org. Chem. 1967, 4, 45. 
6. Charton, M. Prog. Phys. Org. Chem. 1987, 16, 287.

7. Taft, R. W. Steric Effect in Organic Chemistry, Newman, M. S., Ed.; Wiley: New York, 1956; Chapter 3.

8. Note that the reaction temperatures of pyridinolysis $\left(\mathrm{C}_{5} \mathrm{H}_{5} \mathrm{~N}\right)$ and anilinolysis $\left(\mathrm{C}_{6} \mathrm{H}_{5} \mathrm{NH}_{2}\right)$ are 35.0 and $55.0{ }^{\circ} \mathrm{C}$, respectively, and that the substituent effects of the nucleophiles are not considered.

9. Coetzee, J. F.; Padmanabhan, G. R. J. Am. Chem. Soc. 1965, 87, 5005 .

10. Streitwieser, A., Jr.; Heathcock, C. H.; Kosower, E. M. Introduction to Organic Chemistry, 4th ed.; Macmillan Publishing Co.: New York, 1992; 735.

11. The value of $k_{\mathrm{H}} / k_{\mathrm{D}}=2.10$ is the largest primary normal DKIE observed for the anilinolysis of twenty one $\mathrm{R}_{1} \mathrm{R}_{2} \mathrm{P}(=\mathrm{O}) \mathrm{Cl}$-type in $\mathrm{MeCN}$. The primary normal $\left(k_{\mathrm{H}} / k_{\mathrm{D}}>1\right.$; due to a frontside attack involving a hydrogen bonded, four-center TS) and secondary inverse $\left(k_{\mathrm{H}} / k_{\mathrm{D}}<1\right.$; due to a backside nucleophilic attack) DKIEs on the anilinolysis of $\mathrm{R}_{1} \mathrm{R}_{2} \mathrm{P}(=\mathrm{O}$ or $\mathrm{S}) \mathrm{Cl}$-type are discussed extensively in ref 2 . It is common that a backside attack is energetically more favorable than a frontside attack for the anilinolysis of $\mathrm{R}_{1} \mathrm{R}_{2} \mathrm{P}(=\mathrm{O}$ or $\mathrm{S})$ Cl-type when the steric hindrance of the two ligands is not so severe.

12. The CIC is one of the strong tools to elucidate the reaction mechanism. In general, the $\rho_{\mathrm{xz}}$ has a negative value (or sometimes a small positive value) in a concerted $\mathrm{S}_{\mathrm{N}} 2$ reaction and a stepwise reaction with a rate-limiting bond formation. In contrast, it has a positive value for a stepwise reaction with a rate-limiting leaving group departure from the intermediate.: (a) Lee, I. Chem. Soc. Rev. 1990, 19, 317. (b) Lee, I. Adv. Phys. Org. Chem. 1992, 27, 57. (c) Lee, I.; Lee, H. W. Collect. Czech. Chem. Commun. 1999, 64, 1529.

13. (a) Williams, A. Free Energy Relationships in Organic and Bioorganic Chemistry; RSC: Cambridge, UK, 2003; Chapter 7. (b) Ruff, A.; Csizmadia, I. G. Organic Reactions Equilibria, Kinetics and Mechanism; Elsevier: Amsterdam, Netherlands, 1994; Chapter
7. (c) Oh, H. K.; Lee, J. M.; Lee, H. W.; Lee, I. Int. J. Chem. Kinet. 2004, 36, 434. (d) Oh, H. K.; Park, J. E.; Lee, H. W. Bull. Korean Chem. Soc. 2004, 25, 1041. (e) Oh, H. K.; Ku, M. H.; Lee, H. W.; Lee, I. J. Org. Chem. 2002, 67, 8995. (f) Castro, E. A.; Angel, M.; Campodonico, P.; Santos, J. G. J. Org. Chem. 2002, 67, 8911. (g) Castro, E. A.; Pavez, P.; Santos, J. G. J. Org. Chem. 2002, 67, 4494. (h) Oh, H. K.; Ku, M. H.; Lee, H. W.; Lee, I. J. Org. Chem. 2002, 67, 3874. (i) Castro, E. A.; Pavez, P.; Santos, J. G. J. Org. Chem. 2002, 67, 3129. (j) Castro, E. A.; Pavez, P.; Arellano, D.; Santos, J. G. J. Org. Chem. 2001, 66, 6571. (k) Spillane, W. J.; McGrath, P.; Brack, C.; O’Byrne, A. B. J. Org. Chem. 2001, 66, 6313. (1) Koh, H. J.; Han, K. L.; Lee, H. W.; Lee, I. J. Org. Chem. 2000, 65, 4706. (m) Humeres, E.; Debacher, N. A.; Sierra, M. M. D.; Franco J. D.; Shutz, A. J. Org. Chem. 1998, 63, 1598. (n) Baynham, A. S.; Hibbert, F.; Malana, M. A. J. Chem. Soc., Perkin Trans 2 1993, 1711.

14. (a) Jencks, W. P.; Brant, S. R.; Gandler, J. R.; Fendrich, G.; Nakamura, C. J. Am. Chem. Soc. 1982, 104, 7045. (b) Onyido, I.; Swierczek, K.; Purcell, J.; Hengge, A. C. J. Am. Chem. Soc. 2005, 127,7703

15. (a) Lee, I.; Lee, W. H.; Lee, H. W.; Bentley, T. W. J. Chem. Soc., Perkin Trans 2 1993, 141. (b) Chang, S.; Koh, H. J.; Lee, B. S.; Lee, I. J. Org. Chem. 1995, 60, 7760. (c) Jencks, W. P. Chem. Rev. 1985, 85, 511. (d) Bernasconi, C. F. Acc. Chem. Res. 1987, 20, 301. (e) Bernasconi, C. F. Adv. Phys. Org. Chem. 1992, 27, 119.

16. Gilliom, R. D. Introduction to Physical Organic Chemistry; Addison-Wesley; Philippines, 1970; pp 167-169.

17. The isokinetic temperature is calculated from the two nucleophiles with $\mathrm{X}=\mathrm{H}$ and $4-\mathrm{NH}_{2}$, only just to understand the isokinetic relationship. The isokinetic temperature cannot be observed experimentally since the pyridinolysis rate is too fast to measure even at $0.0{ }^{\circ} \mathrm{C}$. 


\section{Kinetics and Mechanism of the Pyridinolysis of Methyl Phenyl Phosphinic Chloride in Acetonitrile}

Keshab Kumar Adhikary and Hai Whang Lee*

Department of Chemistry, Inha University, Incheon 402-751, Korea. "E-mail: hwlee@inha.ac.kr Received April 8, 2011, Accepted April 26, 2011
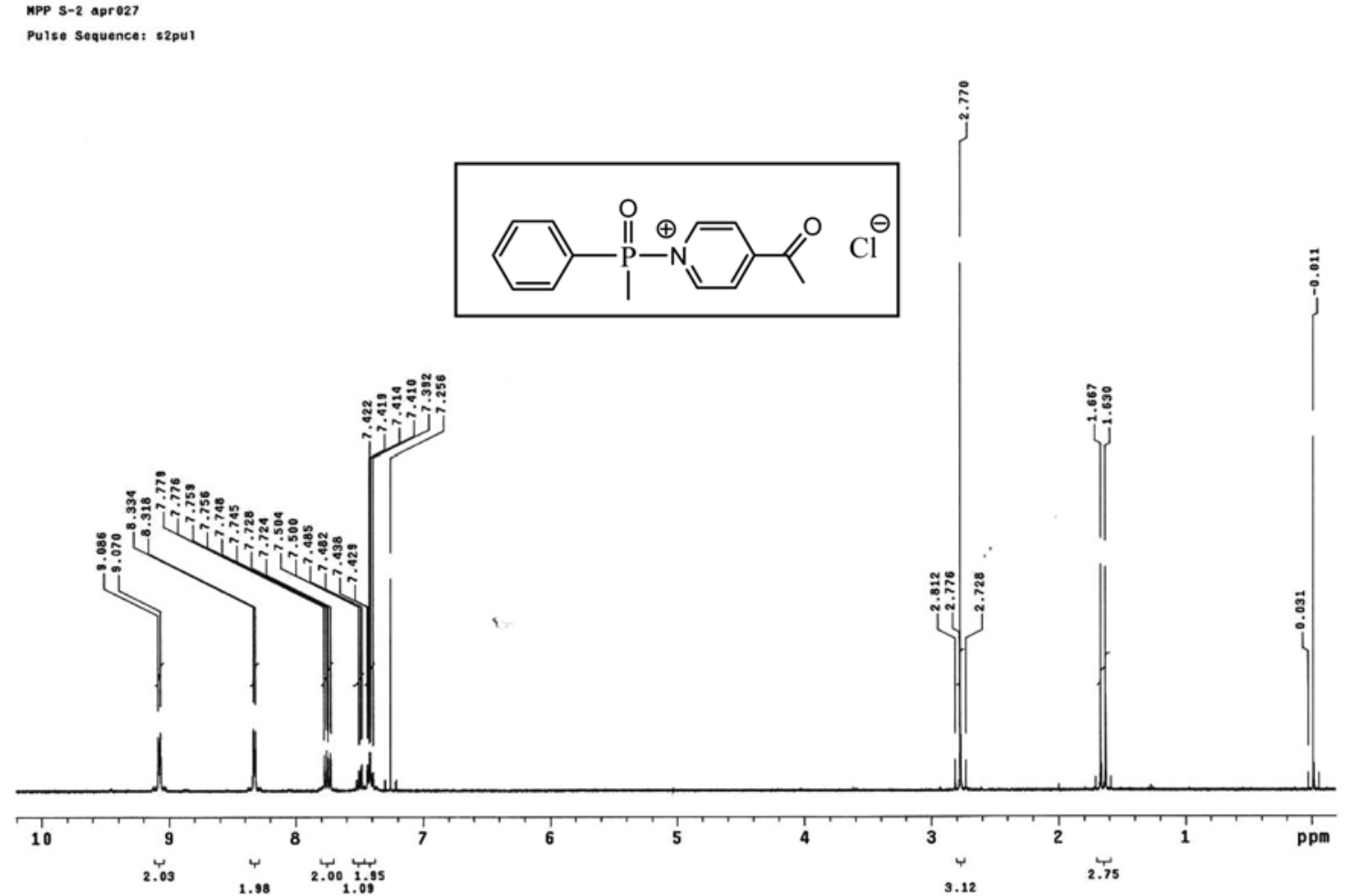

Figure S1. ${ }^{1} \mathrm{H}$ NMR $\left(\mathrm{CDCl}_{3}, 400 \mathrm{MHz}\right)$ spectrum of product $\left[\left(\mathrm{CH}_{3}\right)\left(\mathrm{C}_{6} \mathrm{H}_{5}\right) \mathrm{P}(=\mathrm{O})\left(\mathrm{N}^{+} \mathrm{C}_{5} \mathrm{H}_{4}-4-\mathrm{COCH}_{3}\right) \mathrm{Cl}^{-}\right]$for the reaction of Methyl phenyl phosphinic chloride with 4 -Ac-pyridine in $\mathrm{MeCN}$ at $-20.0{ }^{\circ} \mathrm{C}$. 
MPP S-2 apro2s

Pulse Sequence: s2pu

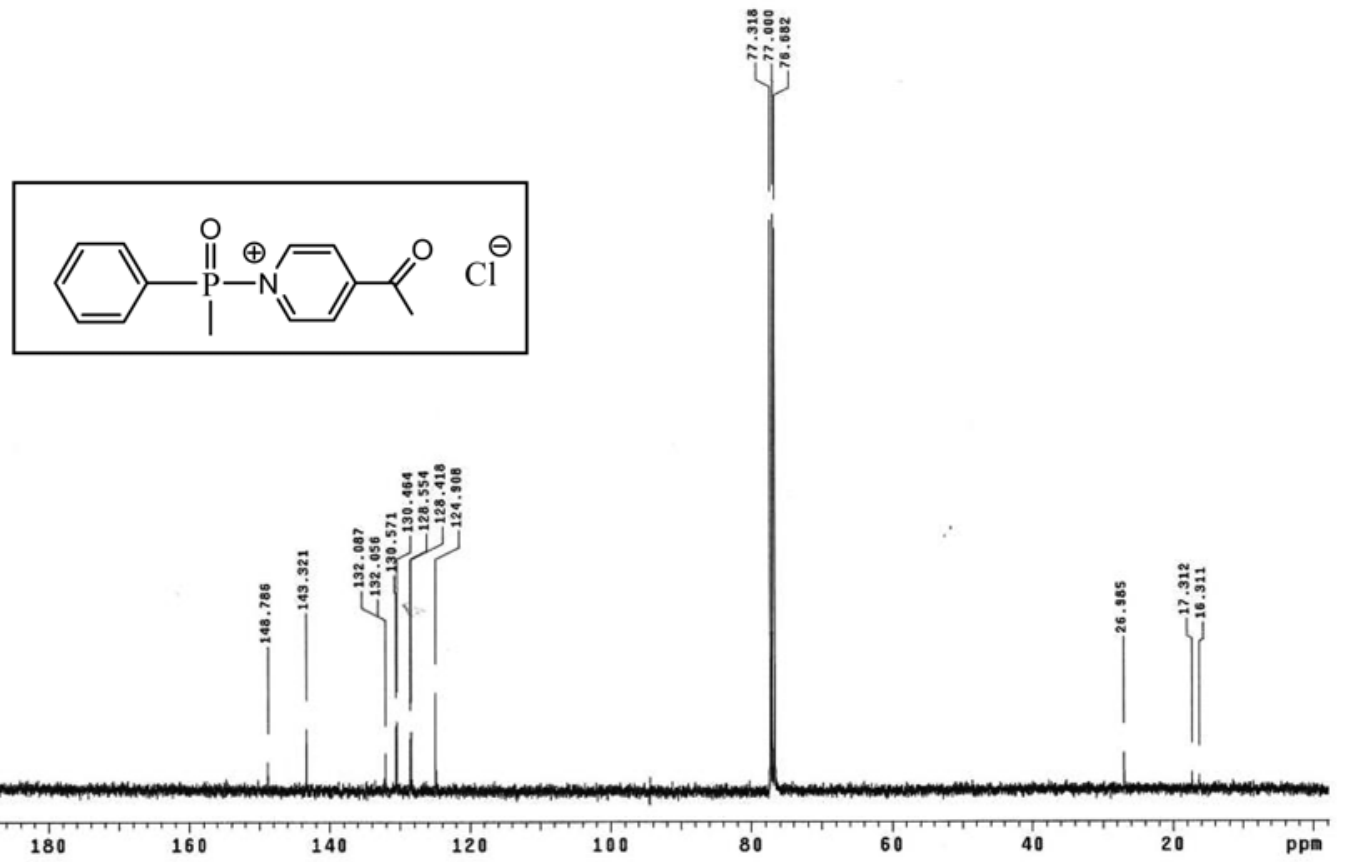

Figure S2. ${ }^{13} \mathrm{C}$ NMR $\left(\mathrm{CDCl}_{3}, 100 \mathrm{MHz}\right)$ spectrum of product $\left[\left(\mathrm{CH}_{3}\right)\left(\mathrm{C}_{6} \mathrm{H}_{5}\right) \mathrm{P}(=\mathrm{O})\left(\mathrm{N}^{+} \mathrm{C}_{5} \mathrm{H}_{4}-4-\mathrm{COCH}_{3}\right) \mathrm{Cl}^{-}\right]$for the reaction of Methyl phenyl phosphinic chloride with 4-Ac-pyridine in $\mathrm{MeCN}$ at $-20.0^{\circ} \mathrm{C}$.

MPP S-2 31P apro2s

Puise sequence: s2pul

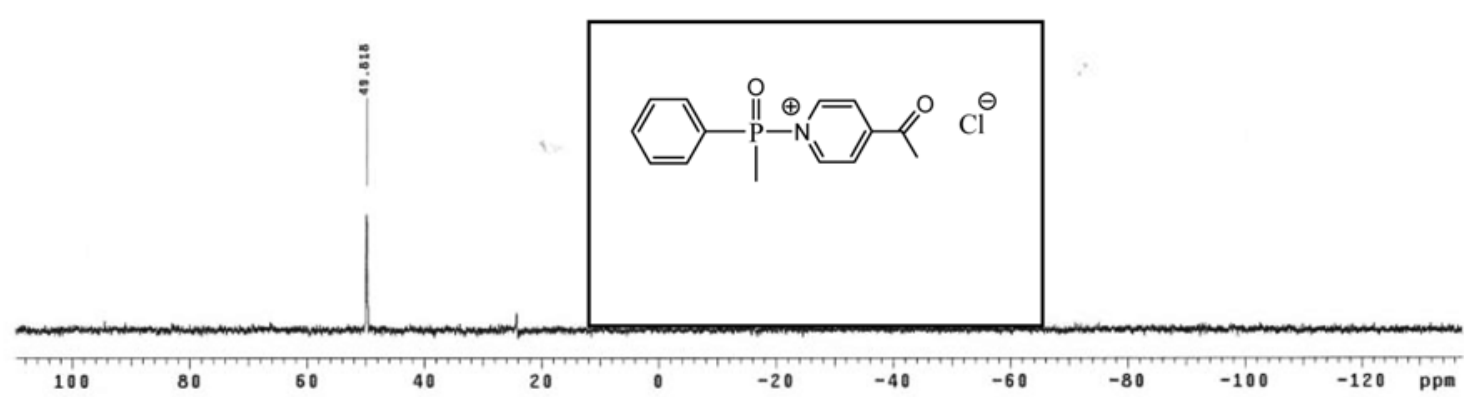

Figure S3. ${ }^{31} \mathrm{P}$ NMR $\left(\mathrm{CDCl}_{3}, 162 \mathrm{MHz}\right)$ spectrum of product $\left[\left(\mathrm{CH}_{3}\right)\left(\mathrm{C}_{6} \mathrm{H}_{5}\right) \mathrm{P}(=\mathrm{O})\left(\mathrm{N}^{+} \mathrm{C}_{5} \mathrm{H}_{4}-4-\mathrm{COCH}_{3}\right) \mathrm{Cl}^{-}\right]$for the reaction of Methyl phenyl phosphinic chloride with 4-Ac-pyridine in $\mathrm{MeCN}$ at $-20.0^{\circ} \mathrm{C}$. 


\section{Print Date: 07 Apr 2011 15:01:20}

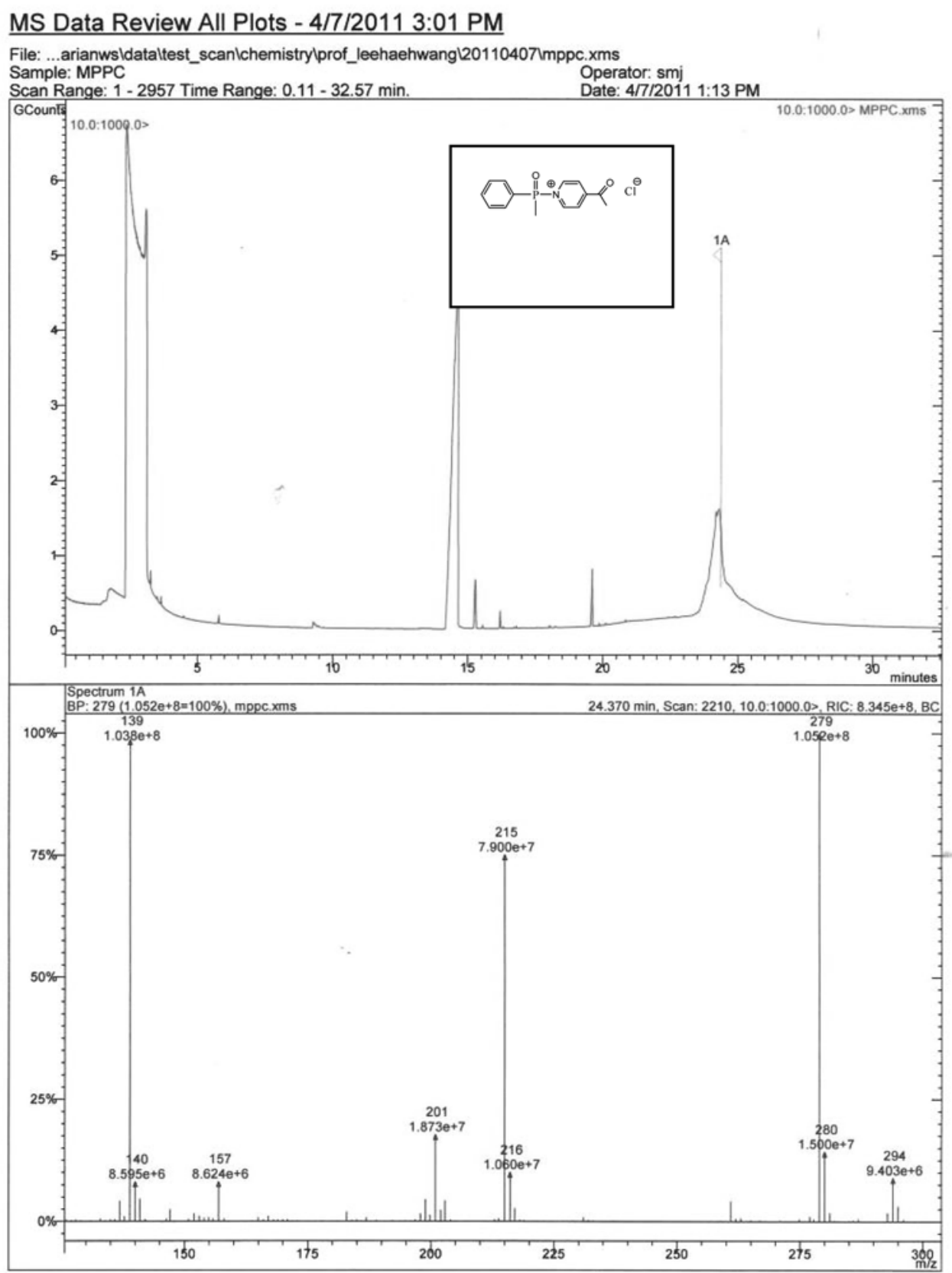

Figure S4. GC-MS spectrum of product $\left[\left(\mathrm{CH}_{3}\right)\left(\mathrm{C}_{6} \mathrm{H}_{5}\right) \mathrm{P}(=\mathrm{O})\left(\mathrm{N}^{+} \mathrm{C}_{5} \mathrm{H}_{4}-4-\mathrm{COCH}_{3}\right) \mathrm{Cl}^{-}\right]$mixtures (reaction solution) for the reaction of Methyl phenyl phosphinic chloride with 4-Ac-pyridine in $\mathrm{MeCN}$ at $-20.0^{\circ} \mathrm{C}$.

Table S1. Activation parameters ${ }^{a}$ for the reactions of Y-O-aryl phenyl phosphonochloridothioates with $\mathrm{XC}_{6} \mathrm{H}_{4} \mathrm{NH}_{2}$ in $\mathrm{MeCN}$.

\begin{tabular}{cccc}
\hline $\mathrm{X}$ & $k_{2} \times 10 / \mathrm{M}^{-1} \mathrm{~s}^{-1}\left({ }^{\circ} \mathrm{C}\right)$ & $\Delta H^{\neq b}$ & $-\Delta S^{\neq c}$ \\
\hline $4-\mathrm{NH}_{2}$ & $10.7(-10.0), 6.10(-20.0)$, & $8.43 \pm 1.3^{d}$ & $26.0 \pm 5.0^{d}$ \\
& $3.71(-25.0)$ & & \\
$\mathrm{H}$ & $558(-20.0), 503(-25.0)$, & $1.8 \pm 0.1$ & $43.0 \pm 0.6$ \\
& $461(-30.0)$ & & \\
$4-\mathrm{CN}$ & $0.0796(0.0), 0.0374(-10.0)$, & $11.1 \pm 0.4$ & $27.3 \pm 1.8$ \\
& $0.0147(-20.0)$ & &
\end{tabular}

${ }^{a}$ Calculated by Eyring equation. ${ }^{b} \mathrm{kcal} \mathrm{mol}{ }^{-1} \cdot{ }^{c} \mathrm{cal} \mathrm{mol}^{-1} \mathrm{~K}^{-1} \cdot{ }^{d}$ Standard deviation. 